\title{
Assortative mating by ethnic background and education among individuals with an immigrant background in Sweden ${ }^{1}$
}

\section{Assortative Mating nach ethnischen und Bildungsgesichtspunkten bei Individuen mit Migrationshintergrund in Schweden}

\begin{abstract}
:
This paper analyzes the determinants of assortative mating by ethnicity and education for individuals with an immigrant background in Sweden, focusing on the role of individual, marriage market and parental characteristics. Results indicate that higher levels of host country specific human capital decrease the likelihood of ethnic endogamy and increase the likelihood of educational homogamy. Opportunity as measured by sex ratios and relative group size is found to be positively correlated to both types of assortative mating. Parental assortative mating (ethnic/educational), as a measure of group identity, is found to increase the likelihood of assortative mating. A comparison of marginal effects, by gender, suggests that the social boundaries defined by ethnicity and education in the marriage market are relatively more easily crossed by men with the accumulation of local and general human capital. Likewise, the influence of group identity appears to matter more for women when marriages are based on ethnicity but matter more for men when marriages are based on education.
\end{abstract}

\begin{abstract}
Zusammenfassung:
In diesem Beitrag werden die Determinanten des nach ethnischen und Bildungsgesichtspunkten ausgerichteten Assortative Mating bei Individuen mit Migrationshintergrund in Schweden untersucht, indem die Rolle individueller und elterlichen Charakteristika sowie die des Heiratmarktes in den Blick genommen werden. Die Ergebnisse legen nahe, dass ein höheres Niveau des für das Aufnahmeland spezifischen Humankapitals die Wahrscheinlichkeit ethnischer Endogamie sinken und die Wahrscheinlichkeit der Bildungshomogamie steigen lässt. Gelegenheitsstrukturen, hier gemessen anhand der Geschlechterratio und der relativen Größe der ethnischen Gruppe, sind jedoch positiv mit beiden Typen des Assortative Mating korreliert. Elterliche Partnerauswahl (nach ethnischen oder Bildungsaspekten) als ein Maß für die ethnische Gruppenidentität erhöht die Wahrscheinlichkeit des Assortative Mating. Ein Vergleich marginaler Effekte nach dem Geschlecht legt nahe, dass die durch die Ethnizität und das Bildungsniveau definierten sozialen Grenzziehungen auf dem Heiratsmarkt von den Männern mit der Akkumulation von örtlichem und allgemeinem Humankapital relativ gesehen - leichter überschritten werden können. Ebenso gilt, dass der Einfluss der Gruppenidentität für Frauen von größerer Bedeutung ist,
\end{abstract}

1 The authors are grateful for comments from Irena Kogan and two anonymous referees as well as seminar participants at the 2008 REASESS Conference. Financial support from the Swedish Council for Working Life and Social Research (FAS) and the Swedish Research Council (VR) is gratefully acknowledged. 
Key words: assortative mating, immigrant background, ethnicity, educational level, marriage market, parental characteristics, sex ratio, group size, gender wenn Eheschließungen auf der Grundlage der Ethnizität erfolgen und dass dieser Einfluss dann für die Männer wichtiger ist, wenn die Eheschließungen auf der Grundlage des Bildungsniveaus erfolgen.

Schlagwörter: Assortative Mating, Migrationshintergrund, Ethnizität, Bildungsniveau, Heiratsmarkt, elterliche Charakteristika, Geschlechterratio, Gruppengröße, Gender

\section{Introduction}

Sweden has a relatively large immigrant population. Today, approximately fifteen percent of the working age population (16-64) is foreign-born. In addition, another 12 percent of the population is born in Sweden with at least one foreign-born parent. There are three main sources of immigration to Sweden. The first concerns migration from the other Nordic countries, primarily Finland, due to the common Nordic labor market established in 1954. The second concerns labor migrants from Southern and Eastern European countries in the 1950s and 1960s recruited to work in the manufacturing sector, which boomed at the time. The third concerns refugee migration. After the mid-1970s, labor migration became more restrictive and refugee migration (as well as immigration due to family reunification) became the largest source of migration to Sweden. Refugee migration to Sweden stemmed from Hungary in the late 1950s, former Czechoslovakia in the late 1960s, Latin America, the Middle East and Africa in the 1970s, former Yugoslavia (mainly Bosnia-Herzegovina) in the 1990s and Iraq in the early 2000s. In 2005, the five largest immigrant groups in Sweden originated from Finland (15 percent of the foreign born population), Iraq ( 7 percent), Yugoslavia (6 percent), Iran (5 percent) and Bosnia-Herzegovina (5 percent).

Before the mid-1970s, the foreign born in Sweden had slightly higher average employment levels than natives and similar income levels. Since the mid-1970s, relative employment rates have dropped and a widening immigrant-native employment and income gap has developed over time. Numerous explanations have been forwarded for this shift in relative employment rates, including structural changes in the industrial sector with a shift away from manufacturing jobs, the changing composition of immigrants, the changes in the underlying motivation for migration, skill-biased technological change promoting soft skills such as language and communication, and discrimination against increasingly "visible" immigrants from predominantly non-European countries. ${ }^{2}$ Lately, attention has turned to how family structure, in particular partnership formation, may influence labor market integration.

2 Note that the shift in immigration in the mid 1970s from predominately labor migration to predominately refugee migration also lead to a shift in the skill composition of the foreign born from relatively unskilled labor migration to relatively skilled refugee migration. Today, the proportion with tertiary educations is approximately the same in the native and foreign born population at roughly 30 percent. See Schröder (2007) for an overview of immigrant-native labor market gaps and integration policy in Sweden. 
How individuals sort into household units has potential implications not only for individual outcomes such as fertility, employment and income but also for the development of social and economic inequality between groups over time and across generations. $\mathrm{Nu}-$ merous studies in the social sciences and biology show that partnership formation is more likely to take place among individuals with similar characteristics, so-called positive assortative mating, on characteristics such as education, income, socioeconomic background, ethnicity, religion and religiosity as well as height, weight, IQ, and social class (Epstein/Guttman 1984; Mare 1991; McPherson et al. 2001; Pencavel 1998).

Explanations vary as to why individuals mate assortatively. Economists tend to focus on the efficiency gains arguing that similarity in certain partner characteristics simplifies, for example, joint decision making and the rearing of children (Becker 1974). The degree of assortative mating in different dimensions can however also be seen as a measure of the degree of openness in the social structures of interest. How individuals of different ethnic origin sort into household units in a multicultural society, like Sweden, can be seen as an indicator of the strength and persistence of social boundaries between ethnic groups. This is important due to the potential long term impact assortative mating has in sustaining economic and social inequality across generations.

The aim of this study is to analyze the determinants of assortative mating patterns along two dimensions, ethnicity and education, for individuals with an immigrant background in Sweden. Immigrant background is defined as being foreign born or born in Sweden with at least one foreign born parent. ${ }^{3}$ Most studies analyze assortative mating patterns in one dimension only. We argue that it is important to consider different types of assortative mating patterns. Over time and across immigrant generations, assortative mating on the grounds of ascribed characteristics (endogamy) such as ethnicity should decline in importance while the role of attained characteristics (homogamy) such as education become increasingly important (Kalmijn 1991b; Giddens 1993).

In the paper, we study how different factors play a role in determining these two types of assortative mating patterns, focusing on the influence of three broad categories of factors; preferences, opportunity and third party involvement. Preferences reflect the role of individual characteristics in determining different types of partnership formation. Here, focus is on characteristics such as age, education, and immigrant status (first or second generation) and duration of residence. Opportunity reflects the role of marriage market characteristics, i.e., the availability of potential spouses with the characteristics of interest. Finally, third party involvement concerns the norms and values that can influence marital choice within the social/ethnic group or family to which an individual belongs. Here, focus is on the influence of parental involvement in partnership formation. The intention of this study is therefore to shed light on how individual, marriage market and parental characteristics influence assortative mating by ethnicity and education among first and second generation immigrants in Sweden.

The remainder of this paper is structured as follows. Section 2 provides a brief overview of the research literature on mating patterns and introduces the theoretical background we utilise as well as the hypotheses we intend to test in this paper. This is fol-

3 The word immigrant will be used in this study to denote both the foreign born (first generation immigrants) and those born in Sweden with at least one foreign born parent (second generation). 
lowed by a description of the data and the analytic strategy in Section 3. Results are presented in Section 4 and concluding remarks in Section 5.

\section{Literature and theory}

\subsection{Brief overview of the literature}

There is a large body of literature on the marriage patterns of different ethnic, immigrant or religious groups. ${ }^{4}$ These studies document for the United States and Europe that a large proportion of immigrants marry within their ethnic or national group or bring spouses from origin countries (Chiswick/Houseworth 2008; Çelikaksoy 2007; Jasso et al. 2000; Lievens 1999; Kalmijin 1993). Endogamous marriages, by national background, are often sustained across generations, although at lower rates and with variations across immigrant groups. Individuals with an immigrant background have the option to marry within their ethnic local marriage market (or bring spouses from origin countries) or marry outside their ethnic marriage market, where the main outside option is intermarrying with a member of the indigenous population in the country of residence or someone with another non-indigenous ethnic background.

Studies looking at intra-marriage within different ethnic groups and intermarriages between immigrants and the indigenous population of the country of residence make use of notions developed in the general research on migration, integration and marriage. ${ }^{5}$ Most studies in this line of research argue that intermarriage is positively associated with the labor market integration of immigrants (Gordon 1964; Lee/Yamanaka 1990; Coleman 1985; Feliciano 2001; Meng/Gregory 2005). One explanation for this correlation is that as immigrants accumulate host country specific human capital, so-called local human capital, such as local language skills, cultural know-how, institutional information and local networks, they develop common characteristics and experiences with other individuals living in that country. ${ }^{6}$ This implies that the boundaries between groups, such as between ethnic groups in the marriage market, become thinner. Ethnic endogamy rates are therefore expected to be negatively correlated with individual characteristics such as immigrant generation, education and years since migration. Indeed, as individuals have higher levels of country specific human capital, the social boundaries defining different marriage markets such as by ethnicity or immigrant background, loose their strength for all parties involved in the decision making process.

There is an even larger body of literature on assortative mating by education. ${ }^{7}$ Empirical studies within this field agree that the correlation between spousal levels of educa-

4 See Qian et al. (2001) for a short review of the literature and Gordon (1964), Lichter/Qian (2001) and Qian/Cobas (2004) for studies on the spousal choice of immigrants.

5 See for example, Lievens (1998), Lichter/Qian (2001), Kalmijn/van Tubergen (2006) and Chiswick/Houseworth (2008).

6 For a detailed explanation of the concept of 'host country specific human capital' see Chiswick/Miller (1995). The terms 'local human capital' and 'host country specific human capital' are used interchangeably in this study.

7 See for example, Buss/Barnes (1986), Henz/Jonsson (2003), Kalmijn (1991a, b) and Mare (1991). 
tion tends to be positive. A number of these studies focus on educational homogamy among individuals with immigrant backgrounds (Angrist 2002; Çelikaksoy et al. 2006; Furtado 2006; Jasso et al. 2000; Kalmijn 1993; Lewis/Oppenheimer 2000; Lievens 1999). The consensus in the majority of these studies is that a positive correlation between the education levels of spouses exists both among those who intermarry (Kalmijn 1993; Lievens 1998; Qian 1999; Qian et al. 2001) as well as those who marry within their ethnic group (Çelikaksoy et al. 2006). The probability of educational homogamy among immigrants is otherwise found to be positively correlated with years of schooling and immigrant generation with some variation by country of origin (Çelikaksoy et al. 2006; Kalmijn 1993; Lievens 1998; Qian 1999; Qian et al. 2001).

Few studies have analyzed the marriage patterns of immigrants in Sweden. Dribe and Lundh (2008) study intermarriages to natives (born in Sweden) among immigrants using cross-sectional data from 2003 and find that better educated immigrants, with longer duration of residence who reside outside the major urban areas are more likely to partner with natives. Behtoui (2008) also studies intermarriage to natives of first and second generation immigrants finding that those with origins outside Northwest Europe and North America have smaller probabilities of intermarrying with natives than immigrants originating in Northwest Europe and North America. The same pattern holds true for second generation immigrants. ${ }^{8}$

\subsection{Theory and hypotheses}

The literature on partnership formation largely focuses on three broad factors thought to influence the decision making process concerning spouse choice; preferences, opportunity for contact, and third party involvement. It is generally assumed that people have a preference for spouses that are similar to themselves in terms of socioeconomic and cultural resources. One reason for this is that the benefits from marriage are thought to be most efficiently utilised when individuals of similar traits match in the marriage market (Becker 1974; Kalmijn 1998; Kalmijn/van Tubergen 2006; Chiswick/Houseworth 2008). ${ }^{9}$ For instance, spouses who have similar values and worldviews will have a relatively easier joint decision making process concerning family issues such as raising children. Becker's theory of marriage therefore predicts positive assortative mating by both socioeconomic and cultural resources such as by educational attainment and ethnic background.

Preferences for a partner with the same ethnic background or level of education may, however, vary across a number of individual characteristics such as own level of education, immigrant generation, duration of residence in the destination country, and country of origin. Individual level of education is pointed out as one of the most important indicators of the values people hold about marriage and family formation and has been found to be negatively correlated with ethnic endogamy and positively correlated with educational homogamy (Kohn 1977; Davis 1982; Kalmijn 1991a, b, 1993, 1998; Mare 1991; Lievens 1998; Qian 1999; Chiswick/Houseworth 2008). Kalmijn (1991b) argues that the

8 See also studies on marriage migration to Sweden (Niedomsyl et al. 2008; Åslund et al., 2009).

9 Becker (1974) predicts positive assortative mating on complementary traits and negative assortative mating on traits that can be substitutes in the household production process. 
rate of assortative mating by ascribed characteristics, such as religion and ethnicity is declining over time while assortative mating on the grounds of attained characteristics such as education is becoming more important.

One reason for this trend can be the overall increase in education levels over time. Educational attainment is generally associated with a weaker emphasis on ascribed characteristics versus attained characteristics as a basis for the evaluation of potential spouses (Kalmijn 1998). Thus, it is expected that education will have a negative association with the likelihood of ethnically endogamous marriages and a positive association with the likelihood of educationally homogamous marriages. Other predictions include that being born in the host country, duration of residence and age are negatively associated with the likelihood of endogamy as local human capital is accumulated through these characteristics. An accumulation of local human capital increases the similarities between groups in the country of residence thereby diminishing the strength of the social boundaries defined by ethnicity in the marriage market.

The relationship between educational homogamy and the accumulation of local human capital is largely unexplored. One can surmise that if the accumulation of local human capital has a similar effect as education in general in weakening the emphasis on ascribed versus attained characteristics as a basis for partner choice, then we can expect a positive association between these characteristics and educational homogamy. However, the role of individual preferences may vary by gender and country of origin as there are differences between these groups in marriage norms, traditions and migration histories.

Over and beyond preferences, the opportunity to meet potential mates is an important factor in partner choice. England/Farkas (1986) and Oppenheimer (1988) use search theory, originally developed for the labor market, to relate the efforts a person exerts to find suitable partners to the restrictions that characterize the marriage market. Two perspectives commonly link marriage market characteristics to marriage formation (Lewis/Oppenheimer, 2000). The first emphasizes sex ratios (Akers 1967; Muhsam 1974; Schoen 1983; Bisin/Verdier 2000). Some immigrant groups may experience unbalanced sexratios in the host country within their ethnic group inducing a higher degree of intermarriage or a search for spouses in home countries. ${ }^{10}$ A second perspective known as the "structuralist" approach focuses on the concentration of ethnic groups rather than sex ratios (Blau 1977; Blau et al. 1982; Blau/Schwartz 1984; Bisin/Verdier 2000). The structuralist approach is concerned with social heterogeneity and group cohesion especially among groups small in size relative to the total population. Limited marriage markets via unbalanced sex ratios within immigrant groups in the host country and small group sizes may therefore induce those with immigrant backgrounds to seek mates outside the relevant local marriage market in the form of interethnic spouses or transnational spouses from origin countries (Angrist 2002; Becker 1974, 1991; Çelikaksoy 2006; Çelikaksoy et al. 2006; Gilbertson et al. 1996; Grossbard-Shechtman 1993).

We therefore expect sex ratio and relative group size to be positively associated with the likelihood of endogamous marriages, since these variables indicate the availability of

10 Unbalanced sex ratios can have economic implications as shown in Becker's (1991) model of marriage and family formation. A change in sex ratios in the direction of a smaller proportion of eligible female candidates, for example, can increase the demand for wives, female marriage rates and family income as females more selectively partner with relatively high income men. 
potential spouses from the same ethnic origin within Sweden. Sex ratios and relative group size by ethnicity may also be positively associated with educational homogamy as a greater number of potential spouses enable individuals to be selective on both characteristics (ethnicity and education).

Finally, spousal choice is likely to be influenced by "third party" involvement, such as from the family, the religious group or the ethnic community. Third parties might have an incentive to keep new generations from marrying outside their relevant group (howsoever defined), since mixed marriages may threaten the internal cohesion and homogeneity of the group. Due to data restriction, we focus in this study only on the potential role of parental involvement in partner selection. In the literature, two main components are discussed through which parental involvement (or third party involvement in general) penetrates into the decision making process concerning spousal choice; group identification and group sanctions.

Children are typically brought up with certain norms and values regarding group identification such as an awareness of a common social history ('a sense of peoplehood') or a sense of being different from others (Gordon 1964; Akerlof/Kranton 2002). Such feelings are expected to be weaker in families where the parents have mixed backgrounds. The more homogenous the background of the parents, the stronger the identification to the group which also implies less variation in the groups that children socialize into. A strong sense of group identification makes it harder to cross social boundaries in the marriage market. In this study, homogeneity in parental background is measured by parental ethnic endogamy and parental educational homogamy, both of which are expected to be positively associated with the probability of respective type of in-group marriage.

In addition to internalized group identification, group sanctions may also play a role in the decision making process of children. There are limited ways in which parents can interfere in their children's spousal choice and these are likely to vary by cultural, religious and educational backgrounds. Parents may set up meetings with potential spouses, play the role of matchmaker, give advice and/or opinions or withdraw financial or emotional support. Depending on the social setting of the relevant group, spousal selection not approved by parents may involve high cultural and psychological costs for the individuals involved. The costs of non-conformist behavior are likely to vary by individualistic versus collectivist societies, cultural and religious background as well as by gender. We therefore expect ethnic endogamy and educational homogamy to vary by country or region of birth.

The preferences of parents with regard to group identification and sanctions will vary by their own characteristics, such as their own level of education and own assortative mating patterns. Relatively higher educated parents may prefer to identify themselves and their group on the grounds of educational attainment while less educated parents may have a preference for ethnically identified groups and thus advise their children on these grounds. Parents with homogenous backgrounds, in turn, may prefer their children to marry in a similar manner. However, marriage norms and third party involvement in children's marriage patterns vary by gender since there is large variation in the role marriage plays in different cultures and religions with regard to gender. Thus, it is predicted that the education of parents will be positively associated with their children's probability of educational homogamy and negatively associated with the probability of ethnic endogamy while the degree of assortative mating among parents will be positively related to both types of marriages. These correlations are expected to vary by gender and country of origin. 


\section{Data and analytic strategy}

\subsection{Data}

The data used in estimation stems from registered information at Statistics Sweden (SCB) on the entire working age population (16-65 years of age) residing in Sweden in 2005. Included in the data is detailed individual information on personal and demographic characteristics, education, employment and income. In addition, information is available on country of birth and migration dates for the foreign-born portion of the population as well as some information on parental characteristics. ${ }^{11}$ Due to partner identification numbers, we are able to link all individuals with their partners. As such, we have detailed information not only on the main individual but also on partners provided that partners fall under the given age restrictions. ${ }^{12}$ Partnership is defined as marriage or cohabitation in a household with joint children. ${ }^{13}$

We restrict the original 2005 sample to individuals in partnerships who are born abroad (first generation immigrants) or born in Sweden with at least one foreign born parent (second generation). Individuals with missing information on partner characteristics are dropped from estimation. ${ }^{14}$ In addition, individuals with missing information on own or both parents' country of birth are dropped from estimation as well as those with one Swedish and one foreign parent but where no information on the country of origin of the foreign parent is available. ${ }^{15}$ These restrictions are necessary in order to define partnerships characterized by similar foreign backgrounds (own or parents), i.e. so-called ethnic endogamy. This gives us a sample of 660,714 individuals with known foreign backgrounds aged 18-65 in partnerships during the year 2005 with detailed information on the main individual and his/her partner.

\subsection{Analytic strategy}

Two types of assortative mating are analyzed in this study, by country of origin (ethnic endogamy) and by level of education (educational homogamy). In both cases, the probability of being in a partnership characterized by positive assortative mating is estimated

11 The data (Statistics on Immigrants - STATIV) was initially created by the Swedish Integration Board but is now maintained by Statistics Sweden.

12 Due to the age restrictions of the data, we lose information on partners above the age of 65 . We can identify the civil status of those with older spouses due to registered information on civil status but we do not have information on spousal characteristics.

13 Data on partnerships stems from information on households. To date, Statistics Sweden tracks only married couples, couples in same-sex registered partnerships and cohabitants with children in common. This implies that we do not have partner information on cohabitants without children.

14 Less than three percent of the original sample is dropped due to missing information on partner characteristics.

15 The original sample of individuals with foreign backgrounds in partnerships consists of 760,120 persons. 515 individuals lack information on own country of birth and 13,268 individuals have no information on either parents' country of birth. An additional 72,078 individuals are dropped due to missing information on the country of birth of the non-Swedish parent. Finally, 3,018 individuals born abroad to two Swedish born parents are also dropped from estimation. 
via a number of probit models controlling for varying sets of individual, marriage market and parental characteristics described in greater detail below. All estimations are run separately by gender. Throughout, coefficient estimates are reported as marginal effects evaluated at the mean of explanatory variables.

Ethnic endogamy is defined as a dichotomous variable equal to one if the main individual is born abroad and the partner is from the same country of origin or, if the partner is born in Sweden, one of the partner's parents is from the same country of origin as the main individual, and zero otherwise. ${ }^{16}$ If the main individual is born in Sweden, ethnic endogamy is equal to one if the partner is born abroad and comes from the same country of origin as at least one of the main individual's (non-Swedish) parents or, if both are born in Sweden, at least one of the parents of both partners is from the same (nonSwedish) country of origin.

Table 1: Definition of ethnic endogamy: Assortative mating by country of origin:

\begin{tabular}{|c|c|c|}
\hline & Partner: & \\
\hline Main individual: & Born Abroad & Born in Sweden \\
\hline Born abroad & $\begin{array}{l}1 \text { if both partners from same country of } \\
\text { origin, } 0 \text { otherwise }\end{array}$ & $\begin{array}{l}1 \text { if at least one of partner's parents has same country of ori- } \\
\text { gin with the observed individual, } 0 \text { otherwise }\end{array}$ \\
\hline Born in Sweden & $\begin{array}{l}1 \text { if partner is from same country of origin } \\
\text { as at least one parent }\end{array}$ & $\begin{array}{l}1 \text { if at least one of the parents is from same (non-Swedish) } \\
\text { country of origin as at least one of partner's parents, } 0 \text { oth- } \\
\text { erwise }\end{array}$ \\
\hline
\end{tabular}

Educational homogamy is defined as a categorical variable equal to one if partners have the same level of completed education and zero otherwise. Six levels of completed education are identified; less than 10 years of compulsory school (denoted as short compulsory), compulsory school (10 years), secondary school (high school/gymnasium), short tertiary, long tertiary (university) and $\mathrm{PhD}$ educations.

To begin with, a number of individual characteristics are controlled for in estimation in order to describe individual preferences for certain types of partners. ${ }^{17}$ As our sample consists of individuals with foreign backgrounds, we control for being born in Sweden with a foreign background, so called second generation status. The reference group for this variable is first generation immigrants (the foreign born). Duration of residence in Sweden is also controlled for in estimation as is region of origin. Region of origin is classified according to a Statistics Sweden classification into eight groups, Nordic, the European Union Fifteen (EU15), other Europe (non-Nordic, non-EU15), North/Central America, South America, Asia/Middle East, Africa and Oceania. Region of origin is based on own country of origin for first generation immigrants and on mother's country of origin for second generation immigrants or, if the mother is born in Sweden, on father's country of origin. Other individual characteristics included in estimation are years of education and age. Age is divided into four categorical variables, 18-29, 30-39, 40-49 and 50 plus, where the reference group is the youngest age cohort (18-29).

16 We recognize that not all ethnic groups are defined by country of origin but use this more general terminology to describe assortative mating patterns by country of birth or parents' country of birth.

17 See also Table A1 in Appendix for a description of variables used in estimation. 
To account for differences in opportunity, two marriage market characteristics are included in estimation, sex ratio and relative group size. Sex ratio is defined as the proportion female to male within each country of origin in the estimations on men, and vice versa, the proportion male to female within each country of origin, in estimations on women. Relative group size is defined as the proportion of females (males) from a given country relative to the population of females (males) in Sweden.

Third party involvement is accounted for by a number of parental characteristics. Mother's and father's education is controlled for, given that this information is available. We include in estimation a categorical variable indicating when information on respective parent's years of education is missing. Two other parental characteristics are also controlled for in estimation, parental ethnic endogamy and parental educational homogamy. Parental ethnic endogamy is equal to one when both parents are known to stem from the same country of origin and zero otherwise. Parental educational homogamy is equal to one when both parents are known to have the same level of education and zero otherwise.

It should be stressed that the analysis presented in this study in no way purports to make causal inferences as current information on mating patterns are used and partners can adjust some characteristics according to each other during the course of their partnership. In addition, data restrictions allow us to analyze only current partnerships without taking into account the number of previous partnerships or the longevity of the current union.

\subsection{Descriptive statistics}

Sample means by gender are reported in Table 2. In comparison to women, a larger proportion of men are in ethnically endogamous partnership whereas the proportions in educationally homogamous partnerships are similar across genders. Other differences include that women, on average, are somewhat younger than men, as well as small differences in the distribution of regional background by gender.

In terms of parental composition, it should be noted that the vast majority ( 98.6 percent) of first generation immigrants have two foreign born parents while the remainder have mixed backgrounds with one Swedish born parent and one foreign born parent. Among second generation immigrants, 30 percent have two foreign-born parents, slightly more have a Swedish born mother (40 percent) while approximately 32 percent have a Swedish born father. This implies that there is a considerable amount of missing information on some parental characteristics especially for first generation immigrants whose parents are less likely to reside in Sweden.

The total proportion with missing information on parental education is reported in Table 2. Seventy percent of observations have no information on mother's level of education across both genders. For reasons unknown to us, there is a considerable amount of missing information on father's level of education for women but not for men. For second generation immigrants (not shown), information on mother's education is available for 63-57 percent of women and men respectively. Father's education is still missing for the vast majority of second generation women but is available for over 90 percent of second generation men. In estimation we include controls for missing information on parental education and therefore measure the effect of respective parent's years of education given that such information 
exists. This implies no loss of observations but less generalizable results on the correlations between female marriage patterns and father's education/parental educational homogamy. Five percent of men are known to have parents with the same level of education.

Table 2: Descriptive statistics, by gender

\begin{tabular}{lcc}
\hline & Female & Male \\
\hline Personal characteristics: & & \\
Ethnic endogamy & 0.39 & 0.42 \\
Educational homogamy & 0.44 & 0.45 \\
Age & 41.26 & 44.18 \\
2nd generation & 0.32 & 0.33 \\
Years residence & 11.69 & 12.58 \\
Years education & 11.38 & 11.43 \\
Missing information on education & 0.039 & 0.031 \\
Nordic & 0.35 & 0.33 \\
EU 15 & 0.10 & 0.13 \\
Other Europe & 0.22 & 0.20 \\
North/Central America & 0.02 & 0.02 \\
South America & 0.03 & 0.03 \\
Asia/Middle East & 0.25 & 0.23 \\
Africa & 0.04 & 0.05 \\
Oceania & 0.002 & 0.003 \\
Parental characteristics: & & \\
Mother's level of education & 10.06 & 10.03 \\
Missing information on mother's education & 0.70 & 0.74 \\
Father's level of education & 11.92 & 11.96 \\
Missing information on father's education & 0.99 & 0.14 \\
Parental ethnic endogamy & 0.17 & 0.16 \\
Parental educational homogamy & 0.004 & 0.05 \\
Number of observations & 340,880 & 319,834 \\
\hline
\end{tabular}

More information is available on the country of origin of respective parent. Indeed this information is available for the majority of second generation immigrants (98 percent have registered information on father's country of birth and over 99 percent on mother's country of birth). For first generation immigrants, information on parent's country of origin is available for over 20 percent of the sample. As shown in Table 2, approximately 16-17 percent of individuals in our sample have parents that are known to originate from the same country of origin.

\section{Empirical results}

\subsection{Ethnic endogamy}

Initially, the probability of being in an ethnically endogamous partnership is estimated by focusing, in turn, on the role of preferences (individual characteristics), opportunity (marriage market characteristics) and third party involvement (parental characteristics). Results, by gender, are shown in Table 3 . 
Results of estimation controlling only for preferences is reported in Table 3, Columns 1 and 4, for females and males respectively. As expected, second generation status is associated with significantly lower ethnic endogamy probabilities in comparison to first generation status as is duration of residence. This is true for both men and women though the reduction attributable to each characteristic is significantly larger for men. These results are in line with theoretical predictions of a decline in ethnic endogamy with years of residence in the host country and across immigrant generations due to increased host country specific human capital. Years of education is also found to be negatively correlated with ethnic endogamy probabilities and, this time, the correlation is significantly larger for women.

As expected, older age groups have significantly higher probabilities of being in ethnically endogamous relationships in comparison to the reference group (18-29) with one exception. For women, no difference is found between those aged 30-39 and the reference group. In estimation age groups serve as a proxy for marriage cohorts and are expected to be positively correlated with ethnic endogamy, as shown. In addition, results may reflect a high survival rate for ethnically endogamous unions formed early in life.

In terms of ascribed characteristics, individuals with background in the EU15 countries, North America and Oceania are less likely to be in ethnically endogamous unions relative to the reference group (Nordic background) while those with backgrounds in other European countries and Asia/Middle East are more likely to be in this type of union. In this simple model, South Americans do not significantly differ from those with Nordic backgrounds in their intra-ethnic union probabilities. One notable difference by gender is that while African women have higher probabilities than Nordic women of being in ethnically endogamous partnerships, African men do not differ from their Nordic counterparts, at least not when estimation controls only for differences in individual characteristics. In general, reported coefficient estimates for regional background are large, suggesting that this ascribed characteristic plays an important role for ethnic endogamy.

In Column 2 and 5, controls for potential differences in opportunity (marriage market characteristics) between ethnic groups are added to the model. Two marriage market characteristics are considered, sex ratios and relative group size. As expected, both characteristics are found to be positively correlated with ethnic endogamy for women. For men, only relative group size has a positive and significant association with the likelihood of being in an ethnically endogamous union. This implies that while the size of the ethnic group influences the probability of intra-ethnic unions for both men and women, the relative availability of members of the opposite sex within the ethnic group only influences female ethnic endogamy probabilities. The size of these coefficients is significantly and considerably larger for women, suggesting that marriage market characteristics are relatively more important factors in limiting the choice of women in the marriage market in comparison to men. For men, individual characteristics, especially those signaling integration into the host country, are instead relatively more important determinants in spousal choice on the grounds of ethnicity.

Note that the inclusion of controls for marriage market characteristics changes a number of the results on individual characteristics reported above. In particular, the negative association between second generation status and ethnic endogamy probabilities increases significantly. Those with South American and African origins are now also found to have a significantly higher likelihood of ethnic endogamy relative to those with Nordic backgrounds, regardless of gender. 
Table 3: The probability of ethnic endogamy

\begin{tabular}{|c|c|c|c|c|c|c|}
\hline & & Female & & & Male & \\
\hline & (1) & (2) & (3) & (4) & $(5)$ & (6) \\
\hline $\begin{array}{l}\text { Preferences: } \\
\text { (Individual characteristics }\end{array}$ & & & & & & \\
\hline 2nd generation & $-0.473^{* *}$ & $-1.000^{* *}$ & $-1.000^{* *}$ & $-0.570^{\star *}$ & $-0.993^{* *}$ & $-0.993^{* *}$ \\
\hline & $(0.002)$ & $(0.000)$ & $(0.000)$ & $(0.002)$ & $(0.000)$ & $(0.001)$ \\
\hline Years residence & $-0.008^{* *}$ & $-0.012^{\star *}$ & $-0.011^{* *}$ & $-0.012^{\star *}$ & $-0.014^{* *}$ & $-0.015^{\star *}$ \\
\hline & $(0.000)$ & $(0.000)$ & $(0.000)$ & $(0.000)$ & $(0.000)$ & $(0.000)$ \\
\hline Years education & $-0.027^{\star \star}$ & $-0.024^{\star *}$ & $-0.023^{\star *}$ & $-0.019^{* *}$ & $-0.017^{\star *}$ & $-0.008^{* *}$ \\
\hline & $(0.000)$ & $(0.000)$ & $(0.000)$ & $(0.000)$ & $(0.000)$ & $(0.001)$ \\
\hline Age 30-39 & -0.004 & $0.030^{* *}$ & $0.025^{\star *}$ & $0.069^{* *}$ & $0.079^{\star *}$ & $0.069^{* *}$ \\
\hline & $(0.003)$ & $(0.003)$ & $(0.003)$ & $(0.005)$ & $(0.005)$ & $(0.005)$ \\
\hline Age $40-49$ & $0.050^{* *}$ & $0.078^{* *}$ & $0.058^{* *}$ & $0.161^{* *}$ & $0.170^{\star *}$ & $0.157^{* *}$ \\
\hline & $(0.003)$ & $(0.003)$ & $(0.004)$ & $(0.004)$ & $(0.004)$ & $(0.005)$ \\
\hline Age $50+$ & $0.094^{* *}$ & $0.136^{\star *}$ & $0.108^{* *}$ & $0.251^{* *}$ & $0.269^{\star *}$ & $0.262^{* *}$ \\
\hline & $(0.004)$ & $(0.004)$ & $(0.005)$ & $(0.005)$ & $(0.005)$ & $(0.005)$ \\
\hline EU15 & $-0.084^{* *}$ & $-0.074^{* *}$ & $-0.069^{* *}$ & $-0.238^{* *}$ & $-0.095^{\star *}$ & $-0.091^{* *}$ \\
\hline & $(0.003)$ & $(0.005)$ & $(0.005)$ & $(0.003)$ & $(0.004)$ & $(0.004)$ \\
\hline Other Europe & $0.138^{* *}$ & $0.324^{* *}$ & $0.325^{\star *}$ & $0.157^{* *}$ & $0.272^{* *}$ & $0.270^{* *}$ \\
\hline & $(0.003)$ & $(0.003)$ & $(0.003)$ & $(0.003)$ & $(0.003)$ & $(0.003)$ \\
\hline North America & $-0.239^{* *}$ & $-0.162^{* *}$ & $-0.156^{* *}$ & $-0.304^{* *}$ & $-0.212^{* *}$ & $-0.210^{* *}$ \\
\hline & $(0.004)$ & $(0.007)$ & $(0.007)$ & $(0.003)$ & $(0.006)$ & $(0.006)$ \\
\hline South America & -0.003 & $0.238^{* *}$ & $0.250^{* *}$ & 0.002 & $0.197^{\star *}$ & $0.199^{* *}$ \\
\hline & $(0.005)$ & $(0.006)$ & $(0.006)$ & $(0.005)$ & $(0.006)$ & $(0.006)$ \\
\hline Asia/Mid. East & $0.188^{* *}$ & $0.360^{* *}$ & $0.364^{* *}$ & $0.203^{* *}$ & $0.350^{\star *}$ & $0.349^{* *}$ \\
\hline & $(0.003)$ & $(0.003)$ & $(0.003)$ & $(0.003)$ & $(0.003)$ & $(0.003)$ \\
\hline Africa & $0.146^{\star *}$ & $0.279^{\star *}$ & $0.284^{* *}$ & 0.002 & $0.219^{* *}$ & $0.223^{* *}$ \\
\hline & $(0.005)$ & $(0.006)$ & $(0.006)$ & $(0.005)$ & $(0.006)$ & $(0.006)$ \\
\hline Oceania & $-0.281^{* *}$ & $-0.317^{\star *}$ & $-0.311^{* *}$ & $-0.347^{* *}$ & $-0.302^{* *}$ & $-0.299^{\star *}$ \\
\hline & $(0.010)$ & $(0.007)$ & $(0.007)$ & $(0.004)$ & $(0.010)$ & $(0.010)$ \\
\hline $\begin{array}{l}\text { Opportunity: } \\
\text { (Marriage market charact }\end{array}$ & & & & & & \\
\hline Sex ratio & & $0.455^{\star *}$ & $0.444^{* *}$ & & 0.001 & $0.006^{*}$ \\
\hline & & $(0.004)$ & $(0.004)$ & & $(0.003)$ & $(0.003)$ \\
\hline Rel. group size & & $0.434^{* *}$ & $0.419^{* *}$ & & $0.248^{* *}$ & $0.247^{\star *}$ \\
\hline & & $(0.003)$ & $(0.003)$ & & $(0.003)$ & $(0.003)$ \\
\hline $\begin{array}{l}\text { Third party involvement: } \\
\text { (Parental characteristics) }\end{array}$ & & & & & & \\
\hline Mother's education & & & $-0.015^{\star \star}$ & & & $-0.017^{* *}$ \\
\hline & & & $(0.001)$ & & & $(0.001)$ \\
\hline Father's education & & & -0.008 & & & $-0.009^{* *}$ \\
\hline & & & $(0.005)$ & & & $(0.001)$ \\
\hline Parental ethnic endogamy & & & $0.037^{* *}$ & & & $0.017^{* *}$ \\
\hline & & & $(0.003)$ & & & $(0.003)$ \\
\hline Pseudo $\mathrm{R}^{2}$ & 0.23 & 0.31 & 0.32 & 0.29 & 0.31 & 0.31 \\
\hline Observations & 340.880 & 340.880 & 340.880 & 319.834 & 319.834 & 319.834 \\
\hline
\end{tabular}

Note: Probit models on the probability of being in a relationship characterized by ethnic endogamy. Coefficient estimates are reported as marginal effects evaluated at the mean of explanatory variables. The reference category is first generation immigrants in the 18-29 age group from the Nordic countries with a median relative education and parents who are not from the same country of origin. Also controlled for in estimation are dummy variables indicating missing information on years of education. Robust standard errors in parentheses. * significant at $5 \%$; ** significant at $1 \%$ 
In the last model, controls for third party involvement (parental characteristics) are included in estimation. Results shown in Column 3 and 6 indicate as expected that parental education is negatively correlated with ethnic endogamy. The coefficient for mother's education is negative and significant for both women and men while the coefficient for fathers' education is significant only for men. As noted earlier, information of father's education is missing for a large proportion of women and results for this variable should therefore be interpreted with caution in estimations on women. Parental ethnic endogamy, i.e. that both parents are born in the same country of origin, is positively associated with ethnic endogamy probabilities for both men and women, but the effect is significantly larger for women. These results are in line with hypotheses predicting lower ethnic endogamy among individuals stemming from families with higher levels of education as such families are likely to identify themselves more on the basis of attained characteristics such as education rather than ascribed characteristics such as ethnicity. Parental ethnic endogamy, in turn, is likely to foster a greater degree of ethnic group identity, all else equal, implying greater cultural/psychological costs for children who marry outside the ethnic group, especially for women.

In separate estimations on preferences, opportunity and third party involvement (not shown), preferences are found to have the greatest explanatory power for ethnic endogamy. Statistics for R-squared range from 23 percent to 29 percent (female and male estimations respectively) while opportunity alone explains only about 18 percent of the variation in ethnic endogamy probabilities, and third party involvement (parental characteristics) alone only between 7-8 percent. However, in the full specification (reported in Column 3 and 6), each block of characteristics is found to be jointly significant, although the inclusion of parental characteristics does not improve $\mathrm{R}^{2}$ statistics markedly once estimation has controlled for individual and marriage market characteristics.

\subsection{Educational homogamy}

Table 4 reports results of probit models on the probability of being in homogamous relationships as defined by education, i.e., the probability of having a partner with the same level of completed education. As above, we begin by analyzing the role of preferences or individual characteristics on educational homogamy (Columns 1 and 4). Second generation status and duration of residence is found to be positively associated with educational homogamy. We therefore have results in line with expectations that greater local human capital decreases assortative mating on ascribed characteristics (ethnicity) and increases assortative mating based on attained characteristics (education) among immigrants in Sweden. Second generation status is associated with about 6 percentage point higher probabilities of being in educationally homogamous relationships in comparison to first generation status. This is a much smaller increase than the likewise decrease of ethnic endogamy among second generation immigrants reported in Table $3 .^{18}$

18 As estimation is based on cross-section data, a strict interpretation is that results reflect differential patterns of educational homogamy and ethnic endogamy by current immigrant generation status rather than a decreasing rate of assortative mating by ethnicity (or an increasing rate of assortative mating by education) over time across generations. 
Age is generally found to be positively associated with educational homogamy with the exception of the oldest age category. Those in the 50 plus category are less likely to be in educationally homogamous relationships in comparison to the younger reference group (insignificant for men). The magnitude of the positive coefficients, however, decreases for older cohorts, which signals a higher likelihood of mating on the grounds of educational attainment for those in the 30-39 cohort. In comparison to estimation on ethnic endogamy, individual characteristics in general appear to have a somewhat weaker correlation to educational homogamy. In addition, considerably less of the variation in this type of assortative mating is explained by observable individual characteristics.

In terms of regional background, "other Europeans" are relatively more likely to assortatively mate according to education, while all other groups show lower relative probabilities to the Nordic reference group, with the exception of women from the EU15 and Oceania who do not significantly differ from Nordic women. Differences between regional groups are found to be smaller for educational homogamy than ethnic endogamy, suggesting that cultural norms concerning intra-ethnic marriage vary more than likewise norms concerning intra-education unions.

Marriage market characteristics are added to estimation in Columns 2 and 5. Both sex ratios and relative group size (defined by ethnicity) are found to be positively correlated with educational homogamy for women while only sex ratios are significant for men. This suggests that a larger number of potential mates within the ethnic group increase the likelihood of assortatively mating on both ethnicity and education, especially for women. Again, the role of opportunity for educational homogamy is found to be smaller than that for ethnic endogamy as reflected in significantly and considerably lower estimated marginal effects. Note also, that the inclusion of marriage market characteristics in estimation alters earlier reported results concerning second generation status for women. Second generation females do not significantly differ from first generation females in their propensity to partner with men of the same educational level when estimation controls for differences in opportunity.

In the full model specification, reported in Column 3 and 6, controls for parental characteristics are added to estimation. Results indicate that parental characteristics are not correlated with educational homogamy for women. For men, father's level of education is negatively correlated with educational homogamy and parental educational homogamy is positively correlated. The result for father's education is at odds with expectations concerning a greater emphasis on attained characteristics such as education for partner choice among children raised in relatively highly educated families. Taken together with the negative association also found between father's education and ethnic endogamy, this results may simply reflect a greater freedom of choice for children in more educated families. The positive association between parental educational homogamy and own educational homogamy, in turn, may reflect a greater focus on gender equality for men raised in educationally egalitarian families. ${ }^{19}$

19 No correlations between father's level of education and educational homogamy for women may again be due to the large degree of missing information on father's education for women. 
Table 4: The probability of educational homogamy

\begin{tabular}{|c|c|c|c|c|c|c|}
\hline & & Female & & & Male & \\
\hline & (1) & (2) & (3) & (4) & (5) & (6) \\
\hline $\begin{array}{l}\text { Preferences: } \\
\text { (Individual characteristics) }\end{array}$ & & & & & & \\
\hline 2nd generation & $0.066^{* *}$ & -0.062 & $-0.117^{* *}$ & $0.059^{* *}$ & $0.110^{* *}$ & $0.065^{*}$ \\
\hline & $(0.003)$ & $(0.033)$ & $(0.033)$ & $(0.003)$ & $(0.028)$ & $(0.029)$ \\
\hline Years residence & $0.002^{* *}$ & $0.002^{* *}$ & $0.001^{\star *}$ & $0.002^{\star *}$ & $0.002^{* *}$ & $0.001^{* *}$ \\
\hline & $(0.000)$ & $(0.000)$ & $(0.000)$ & $(0.000)$ & $(0.000)$ & $(0.000)$ \\
\hline Years education & $0.010^{* *}$ & $0.011^{* *}$ & $0.011^{* *}$ & $0.015^{\star *}$ & $0.015^{\star *}$ & $0.041^{* *}$ \\
\hline & $(0.000)$ & $(0.000)$ & $(0.000)$ & $(0.000)$ & $(0.000)$ & $(0.001)$ \\
\hline Age 30-39 & $0.026^{\star *}$ & $0.027^{\star *}$ & $0.031^{* *}$ & $0.038^{* *}$ & $0.038^{* *}$ & $0.031^{* *}$ \\
\hline & $(0.003)$ & $(0.003)$ & $(0.003)$ & $(0.004)$ & $(0.004)$ & $(0.004)$ \\
\hline Age $40-49$ & $0.008^{* *}$ & $0.008^{* *}$ & $0.018^{* *}$ & $0.019^{* *}$ & $0.020^{* *}$ & $0.021^{* *}$ \\
\hline & $(0.003)$ & $(0.003)$ & $(0.003)$ & $(0.004)$ & $(0.004)$ & $(0.004)$ \\
\hline Age $50+$ & $-0.009^{\star *}$ & $-0.007^{\star}$ & $0.009^{*}$ & -0.003 & -0.002 & $0.010^{*}$ \\
\hline & $(0.003)$ & $(0.003)$ & $(0.004)$ & $(0.004)$ & $(0.004)$ & $(0.004)$ \\
\hline EU15 & 0.002 & $-0.010^{* *}$ & $-0.010^{* *}$ & $-0.018^{* *}$ & $-0.015^{\star *}$ & $-0.014^{* *}$ \\
\hline & $(0.003)$ & $(0.003)$ & $(0.003)$ & $(0.003)$ & $(0.003)$ & $(0.003)$ \\
\hline Other Europe & $0.019^{* *}$ & $0.026^{\star *}$ & $0.025^{\star *}$ & $0.021^{* *}$ & $0.019^{* *}$ & $0.017^{* *}$ \\
\hline & $(0.003)$ & $(0.003)$ & $(0.003)$ & $(0.003)$ & $(0.003)$ & $(0.003)$ \\
\hline North America & $-0.015^{\star}$ & $-0.021^{* *}$ & $-0.021^{* *}$ & $-0.036^{\star *}$ & $-0.035^{\star \star}$ & $-0.034^{\star *}$ \\
\hline & $(0.006)$ & $(0.006)$ & $(0.006)$ & $(0.006)$ & $(0.006)$ & $(0.006)$ \\
\hline South America & $-0.015^{\star \star}$ & $-0.011^{\star}$ & $-0.014^{\star *}$ & $-0.015^{\star *}$ & $-0.017^{\star *}$ & $-0.020^{* *}$ \\
\hline & $(0.005)$ & $(0.005)$ & $(0.005)$ & $(0.005)$ & $(0.006)$ & $(0.006)$ \\
\hline Asia/Mid. East & $-0.059^{* *}$ & $-0.058^{* *}$ & $-0.061^{* *}$ & $-0.067^{* *}$ & $-0.067^{\star *}$ & $-0.068^{* *}$ \\
\hline & $(0.003)$ & $(0.003)$ & $(0.003)$ & $(0.003)$ & $(0.003)$ & $(0.003)$ \\
\hline Africa & $-0.098^{* *}$ & $-0.107^{\star *}$ & $-0.108^{* \star}$ & $-0.114^{\star *}$ & $-0.112^{\star *}$ & $-0.110^{* *}$ \\
\hline & $(0.005)$ & $(0.005)$ & $(0.005)$ & $(0.004)$ & $(0.005)$ & $(0.005)$ \\
\hline Oceania & -0.039 & $-0.070^{* *}$ & $-0.071^{* *}$ & $-0.070^{* *}$ & $-0.064^{* *}$ & $-0.062^{\star *}$ \\
\hline & $(0.021)$ & $(0.021)$ & $(0.021)$ & $(0.017)$ & $(0.017)$ & $(0.017)$ \\
\hline $\begin{array}{l}\text { Opportunity: } \\
\text { (Marriage market characterist }\end{array}$ & & & & & & \\
\hline Sex ratio & & $0.055^{\star *}$ & $0.058^{* *}$ & & $0.020^{* *}$ & $0.019^{\star *}$ \\
\hline & & $(0.003)$ & $(0.003)$ & & $(0.003)$ & $(0.003)$ \\
\hline Rel. group size & & $0.012^{* *}$ & $0.015^{\star *}$ & & -0.005 & -0.004 \\
\hline & & $(0.003)$ & $(0.003)$ & & $(0.003)$ & $(0.003)$ \\
\hline $\begin{array}{l}\text { Third party involvement: } \\
\text { (Parental characteristics) }\end{array}$ & & & & & & \\
\hline Mother's education & & & 0.001 & & & 0.001 \\
\hline & & & $(0.000)$ & & & $(0.001)$ \\
\hline Father's education & & & -0.002 & & & $-0.028^{* *}$ \\
\hline & & & $(0.002)$ & & & $(0.001)$ \\
\hline Parental education homogamy & & & 0.010 & & & $0.079^{* *}$ \\
\hline & & & $(0.017)$ & & & $(0.005)$ \\
\hline Pseudo $\mathrm{R}^{2}$ & 0.01 & 0.01 & 0.01 & 0.01 & 0.02 & 0.02 \\
\hline Observations & 340.880 & 340.880 & 340.880 & 319.834 & 319.834 & 319.834 \\
\hline
\end{tabular}

Note: Probit models on the probability of being in a relationship characterized by educational homogamy. Coefficient estimates are reported as marginal effects evaluated at the mean of explanatory variables. Reference category is first generation immigrants in the 18-29 age group from the Nordic countries with a median relative education and parents who are do not have the same level of education. Also controlled for in estimation are dummy variables indicating missing information on years of education. Robust standard errors in parentheses. * significant at 5\%; ** significant at $1 \%$

Note also, that the coefficient for second generation status among women changes again with the inclusion of controls for parental characteristics in estimation. Second generation 
women are now found to be associated with lower probabilities of being in educationally homogamous unions in comparison to first generation women. This implies that theories concerning the importance of host country specific human capital for an increased focus on attained characteristics such as education in spousal choice only partially pan out in estimation on women. Results may also reflect a selection of first generation female migrants with high levels of educationally homogamous unions.

In general, very little of the variation in educational homogamy probabilities is explained by observed characteristics as shown by low R-squared statistics. Given these low levels, slightly more of the variation in educational homogamy is explained by observed characteristics for men than women. Clearly, observed characteristics (attained and ascribed) play a larger role for spousal choice based on ethnicity than spousal choice based on education for immigrants in Sweden.

\subsection{Assortative mating among immigrants with backgrounds in Finland and Iraq}

Results reported above reflect the influence of different factors to assortative mating probabilities on average for immigrant groups in Sweden. Due to variations in cultural norms concerning marriage, varying degrees of parental involvement and varying traditions concerning partnerships formation, it is likely that there is a great deal of heterogeneity between ethnic groups in how these characteristics influence partnership formation. We therefore reestimate our equations on ethnic endogamy and educational homogamy for two of the largest immigrant groups in Sweden, i.e. people from Finland and Iraq. These two groups also represent the two main types of immigrant groups which came to Sweden, namely labor market migrants and refugee migrants, and also stem from two areas of the world with potentially very different norms and traditions concerning partnership formation.

Unadjusted averages indicate that 25 percent of Finnish and 94 percent of Iraqi women are currently in ethnically endogamous relationships. Likewise rates for men are 30 and 85 percent for those with Finnish and Iraqi backgrounds respectively. Table 5 reports results for estimation on the probability of being in an ethnically endogamous union. ${ }^{20}$ Results indicate considerable heterogeneity in the determinants of ethnic endogamy between these two immigrant groups as well as by gender. Duration of residence is, for example, negatively correlated to ethnic endogamy for all groups, but has a quantitatively larger effect for men (largest for Iraqi men). Education is found to be negatively correlated with ethnic endogamy probabilities for all groups except Iraqi men, but with larger marginal effects for those with Finnish backgrounds. Age is negatively correlated with ethnic endogamy for the Finnish but positively correlated with ethnic endogamy for Iraqis. The finding that older Iraqi cohorts are more likely to marry endogamously and vice versa for Finns, may reflect the importance of changing preferences across marriage cohorts for Iraqis, whereas for Finns, it is rather a reflection of changing marriage market conditions.

20 Note that information on marriage market characteristics do not vary within national groups and are therefore dropped from estimation. 
Table 5: The probability of ethnic endogamy, Finland and Iraq

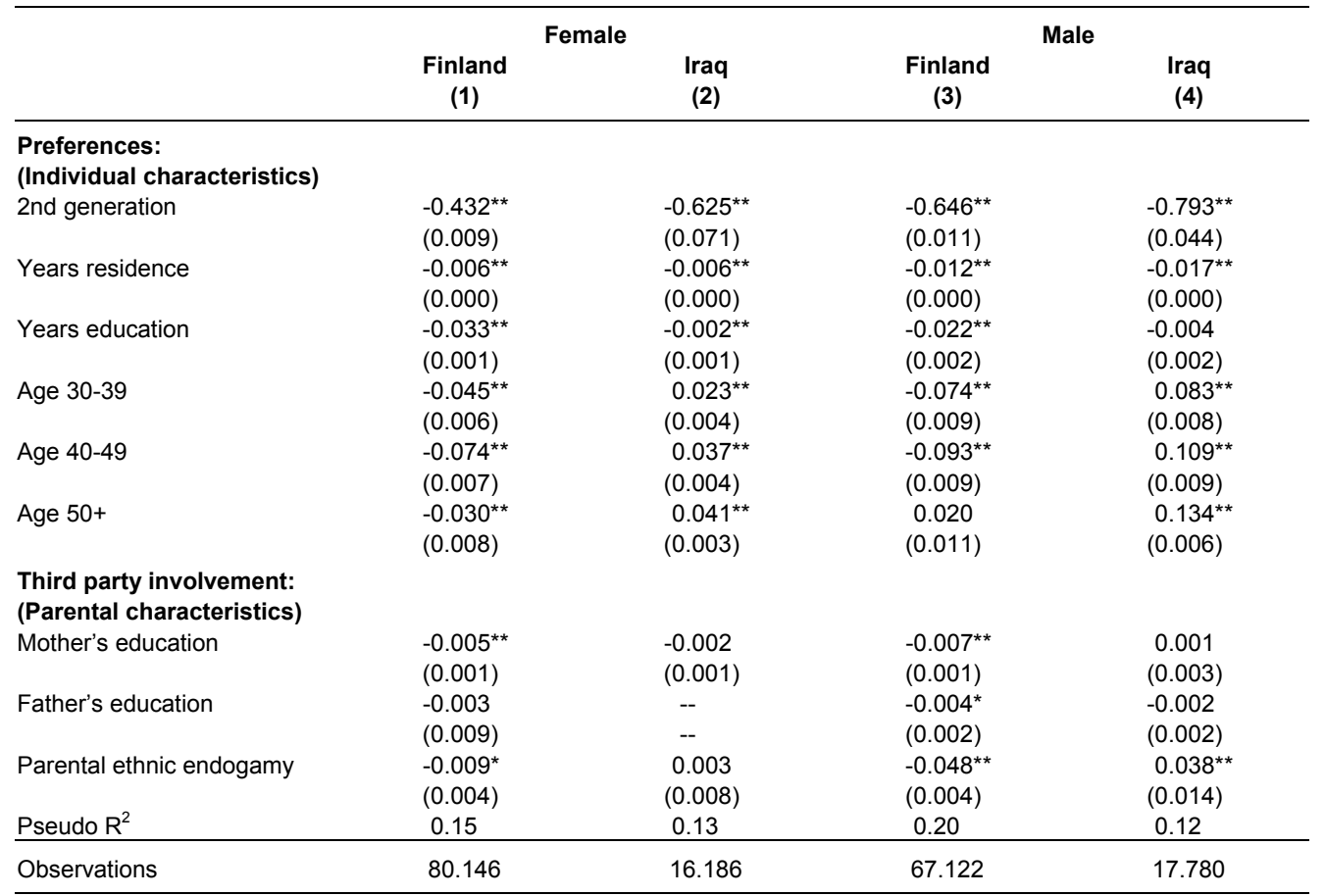

Note: Probit models on the probability of being in a relationship characterized by ethnic endogamy for those with Finnish or Iraqi backgrounds. Coefficient estimates are reported as marginal effects evaluated at the mean of explanatory variables. The reference category is first generation immigrants in the 18-29 age group with a median relative education and parents who are not from the same country of origin. Also controlled for in estimation are dummy variables indicating missing information on years of education. Robust standard errors in parentheses. ${ }^{*}$ significant at $5 \% ; * *$ significant at $1 \%$

In terms of third party involvement, mother's education is significantly and negatively correlated with ethnic endogamy for the Finnish but insignificant for the Iraqi group, regardless of gender. Finally parental ethnic endogamy has a negative correlation with ethnic endogamy for the Finnish group (quantitatively small coefficient for Finnish women) but a positive correlation for Iraqi men and no significance for Iraqi women.

Turning instead to educational homogamy probabilities for those with Finnish and Iraqi backgrounds, results shown in Table 6 indicate again considerable heterogeneity in the determinants of this type of union between these two immigrant groups. Unadjusted averages indicate much lower variation in educational homogamy across these two countries than that found for ethnic endogamy. 48 percent of the Finnish and Iraqis are in educationally homogamous relationships, regardless of gender. Estimation results indicate that only Iraqi men have an increased probability of educational homogamy among second generation immigrants. No such correlation is found for the other groups. Years of education is positively correlated with educational homogamy for all groups with the exception of Finnish females, where the association is negative and significant. Age is again found to be negatively associated with assortative mating probabilities for those with Fin- 
nish backgrounds and positively associated for those with Iraqi backgrounds. Parental characteristics appear to matter more for male educational homogamy probabilities than for likewise female probabilities. ${ }^{21}$ However, mother's education only has a negative influence on male Finnish educational homogamy while father's education influences both Finnish and Iraqi men (negatively). Parental educational homogamy has a positive association with educational homogamy probabilities for Finnish men but a negative association with educational homogamy for Iraqi men.

Table 6: The probability of educational homogamy, Finland and Iraq

\begin{tabular}{|c|c|c|c|c|}
\hline & \multicolumn{2}{|c|}{ Female } & \multicolumn{2}{|c|}{ Male } \\
\hline & $\begin{array}{c}\text { Finland } \\
\text { (1) }\end{array}$ & $\begin{array}{l}\text { Iraq } \\
(2)\end{array}$ & $\begin{array}{c}\text { Finland } \\
\text { (3) }\end{array}$ & $\begin{array}{l}\text { Iraq } \\
(4)\end{array}$ \\
\hline \multicolumn{5}{|l|}{$\begin{array}{l}\text { Preferences: } \\
\text { (Individual characteristics) }\end{array}$} \\
\hline 2nd generation & $\begin{array}{c}0.007 \\
(0.012)\end{array}$ & $\begin{array}{c}0.089 \\
(0.066)\end{array}$ & $\begin{array}{c}0.011 \\
(0.015)\end{array}$ & $\begin{array}{r}0.211^{*} \\
(0.084)\end{array}$ \\
\hline Years residence & $\begin{array}{l}-0.000 \\
(0.000)\end{array}$ & $\begin{array}{l}-0.002 \\
(0.001)\end{array}$ & $\begin{array}{c}0.001 \\
(0.000)\end{array}$ & $\begin{array}{l}-0.001 \\
(0.001)\end{array}$ \\
\hline Years education & $\begin{array}{l}-0.011^{* *} \\
(0.001)\end{array}$ & $\begin{array}{l}0.028^{* *} \\
(0.001)\end{array}$ & $\begin{array}{l}0.050^{* *} \\
(0.002)\end{array}$ & $\begin{array}{l}0.034^{* *} \\
(0.003)\end{array}$ \\
\hline Age $30-39$ & $\begin{array}{l}-0.005 \\
(0.007)\end{array}$ & $\begin{array}{l}0.061^{* *} \\
(0.011)\end{array}$ & $\begin{array}{l}-0.027^{* *} \\
(0.010)\end{array}$ & $\begin{array}{l}0.073^{* *} \\
(0.015)\end{array}$ \\
\hline Age $40-49$ & $\begin{array}{l}-0.048^{* *} \\
(0.008)\end{array}$ & $\begin{array}{l}0.109^{\star *} \\
(0.012)\end{array}$ & $\begin{array}{l}-0.084^{* *} \\
(0.010)\end{array}$ & $\begin{array}{l}0.112^{* *} \\
(0.015)\end{array}$ \\
\hline Age $50+$ & $\begin{array}{l}-0.083^{* *} \\
(0.009)\end{array}$ & $\begin{array}{l}0.100^{* *} \\
(0.017)\end{array}$ & $\begin{array}{l}-0.104^{* *} \\
(0.011)\end{array}$ & $\begin{array}{c}0.096^{* *} \\
(0.017)\end{array}$ \\
\hline \multicolumn{5}{|l|}{$\begin{array}{l}\text { Third party involvement: } \\
\text { (Parental characteristics) }\end{array}$} \\
\hline Mother's education & $\begin{array}{l}-0.000 \\
(0.001)\end{array}$ & $\begin{array}{c}0.003 \\
(0.004)\end{array}$ & $\begin{array}{l}-0.006^{* *} \\
(0.001)\end{array}$ & $\begin{array}{l}-0.004 \\
(0.005)\end{array}$ \\
\hline Father's education & $\begin{array}{l}-0.014 \\
(0.007)\end{array}$ & $\begin{array}{l}-- \\
--\end{array}$ & $\begin{array}{l}-0.032^{* *} \\
(0.002)\end{array}$ & $\begin{array}{l}-0.022^{* *} \\
(0.003)\end{array}$ \\
\hline Parental education homogamy & $\begin{array}{c}0.015 \\
(0.055)\end{array}$ & $\begin{array}{l}-- \\
--\end{array}$ & $\begin{array}{l}0.105^{\star *} \\
(0.007)\end{array}$ & $\begin{array}{l}-0.130^{*} \\
(0.053)\end{array}$ \\
\hline Pseudo $\mathrm{R}^{2}$ & 0.01 & 0.05 & 0.02 & 0.02 \\
\hline Observations & 80146 & 16186 & 67122 & 17780 \\
\hline
\end{tabular}

Note: Probit models on the probability of being in a relationship characterized by educational homogamy for those with Finnish and Iraqi backgrounds. Coefficient estimates are reported as marginal effects evaluated at the mean of explanatory variables. Reference category is first generation immigrants in the 18-29 age with a median relative education and parents who are do not have the same level of education. Also controlled for in estimation are dummy variables indicating missing information on years of education. Robust standard errors in parentheses. ${ }^{*}$ significant at $5 \% ; * *$ significant at $1 \%$

21 As noted earlier, information on father's education is missing for a large proportion of women in the sample. This is not the case for mother's education. As such, noted differences on the effect of mother's education are externally valid while interpretations of coefficients for fathers' level of education should be made with caution in estimation on women. 


\section{Conclusions}

This study analyzes the determinants of assortative mating by ethnic background (ethnic endogamy) and education (educational homogamy) focusing on the potential role of preferences, opportunity and third party involvement for spousal choice. Estimation is based on the population of working age individuals with an immigrant background, in partnerships, residing in Sweden in 2005.

Results are largely in line with theories suggesting that higher levels of host country specific human capital decrease the likelihood of ethnic endogamy and increase the likelihood of educational homogamy. Both second generation status and duration of residence is found to be negatively correlated with ethnic endogamy probabilities and positively correlated with educational homogamy probabilities with one exception. Second generation women are less likely to be in educationally homogamous relationships than first generation women once controls for differences in marriage market and parental characteristics are included in estimation.

Years of education is also found to be negatively correlated with ethnic endogamy and positively correlated with educational homogamy in line with predictions concerning a greater orientation towards attained characteristics such as education and lower orientation towards ascribed characteristics such as ethnicity with higher levels of education (own and parents). Age as a proxy for marriage cohorts is found to be positively correlated to ethnic endogamy and negatively correlated to educational homogamy, as expected. This may be a reflection of a higher degree of emphasis on educational attainment versus ethnic background for younger cohorts among the immigrant population in Sweden.

Variation in assortative mating probabilities is found by regional background for both types of unions. However, this variation is larger between regional groups in estimation of ethnic endogamy suggesting that varying cultural norms about marriage matter more for assortative mating in terms of ethnicity. This general trend is further confirmed when two culturally distinct groups, i.e. Finns and Iraqis, are compared. The determinants of respective type of assortative mating are found to vary by both country of origin and gender.

Opportunity as measured by sex ratios and relative group size is found to be positively correlated to ethnic endogamy. A comparison of the magnitude of the marginal effects suggests that relative group size and sex ratios have a larger impact on assortative mating by ethnicity for women. Estimation also indicates that a larger number of potential mates within the ethnic group (sex ratios) increase the likelihood of assortative mating on education suggesting that individuals can assortatively mate along both dimensions. The role of opportunity for educational homogamy is found to be smaller than that for ethnic endogamy as reflected by significantly and considerably lower estimated marginal effects.

Father's education is found to be negatively correlated with both ethnic endogamy and educational homogamy for men. The latter result is somewhat unexpected but may reflect a greater freedom of choice in spousal selection among men raised in relatively well educated families. Finally, parental ethnic endogamy is positively associated with own ethnic endogamy while parental educational homogamy is positively associated with own educational homogamy (men). 
Our findings indicate that the accumulation of local human capital has a similar role to play as educational attainment; both indicate a shift in preferences in the direction from ascribed characteristics to attained characteristics as a basis for spousal choice. Results indicate that observable individual characteristics play a relatively more important role for male preferences for assortative mating both on the grounds of ethnicity and education, than for female preferences, suggesting that the social boundaries defined by ethnicity in the marriage market can more easily be crossed by males with the accumulation of local and general human capital. In our main models, we also find that the availability of potential spouses in the relevant group increases the probability of intra-group marriages, but the strength of these variables are again stronger for females than that for males, suggesting that marriage market constraints are relatively more binding for females. In addition, parental assortative mating (ethnic/educational) indicators measuring group identity are significantly larger for females than for males in terms of ethnically endogamous marriages and vice versa for educationally homogamous marriages. This result suggests that group identity is relatively more important for females in terms of intra-ethnic marriages and relatively more important for males in terms of educationally homogamous marriages, although there are variations by country of origin.

Taken together, our results suggest that mating along the lines of ascribed characteristics such as ethnicity will decrease over time and across immigrant generations. This is in turn an indicator of social integration between immigrants and natives suggesting that social inequalities between groups should diminish over time, albeit with variations across gender and immigrant groups, due to varying norms about marriage as well as varying parental and community involvement in the marriage decision.

\section{References}

Akerlof, G.A \& Kranton R.E. (2002). Identity and schooling: Some lessons for the economics of Education. Journal of Economic Literature, vol. 40(4), pp. 1167-1201.

Akers, D. S. (1967). On measuring the marriage squeeze, Demography, 4, pp. 907-24.

Angrist, J. (2002). How do sex ratios affect marriage and labour markets? Evidence from America's second generation. Quarterly Journal of Economics, 117(3), pp. 997-1038.

Åslund, O., Böhlmark, A. \& Skans Nordström, O. (2009). Age at immigration and social integration. Uppsala: Institutet för arbedsmarknadspolitisk utvärdering (IFAU), (Mimeo).

Becker, G. S. (1974). A theory of marriage. Economics of the Family, Chicago, London: University of Chicago Press, pp. 299-344.

Becker, G. S. (1991). A treatise on the family. Cambridge, MA: Harvard University Press.

Behtoui, A. (2009, forthcoming). Marriage patterns of immigrants in Sweden. Journal of Comparative Family Studies.

Bisin, A. \& Verdier, T. (2000). Beyond the melting pot: Cultural transmission, marriage and the evolution of ethnic and religious traits. Quarterly Journal of Economics, Vol. 11, pp. 955-988.

Blau, P. M. (1977). Inequality and heterogeneity. New York: Free Press.

Blau, P. M., Blum, T. C. \& Schwartz, J. E (1982). Heterogeneity and intermarriage. American Sociological Review, 47, pp. 45-62.

Blau, P. M. \& Schwartz, J. E. (1984). Crosscutting social circles. New York: Academic Press.

Buss, D. M. \& Barnes, M. (1986). Preferences in human mate selection. Journal of Personality and Social Psychology, 50, pp. 559-570. 
Chiswick, B. R. \& Miller, P. W. (1995). The endogeneity between language and earnings: International analyses. Journal of Labor Economics, 13 (2), pp. 246-288.

Chiswick, B. R. \& Houseworth, C. A. (2008). Ethnic intermarriage among immigrants: Human capital and assortative mating. Bonn: Institute for the Study of Labor (IZA Discussion Paper No. 3740).

Coleman, D. A. (1985). Interethnic marriage in Great Britian. Population Trends, 40, pp. 4-10.

Çelikaksoy, A., Nielsen. H. S. \& Verner, M. (2006). Marriage migration: Just another case of positive assortative matching? Review of Economics of the Household, 4, pp. 271-293.

Çelikaksoy, A. (2006). Marriage behaviour and labour market integration: The case of the children of guest worker immigrants in Denmark. Aarhus: Aarhus School of Business. Department of Economics ( $\mathrm{PhD}$ thesis).

Çelikaksoy, A. (2007). A wage premium or penalty: An analysis of endogamous marriage effects among the children of immigrants? Danish Journal of Economics, 145 (3). pp. 288-311.

Davis, J. A. (1982). Achievement variables and class cultures: Family, schooling, and forty-nine dependent variables in the cumulative GSS. American Sociological Review, 47, pp. 569-586.

Dribe, M. \& Lundh, C. (2008). Intermarriage and immigrant integration in Sweden: An exploratory analysis. Acta Sociologica, Vol. 51, No. 4, pp. 329-354.

England, P. \& Farkas, G. (1986). Households, employment and gender. New York: Aldine.

Epstein, E. \& Guttman, R. (1984). Mate selection in man: Evidence, theory and outcome. Social Biology, 31(4), pp. 243-278.

Feliciano, C. (2001). Assimilation or enduring racial boundaries? Generational differences in intermarriage among Asians and Latinos in the United States. Race and Society, 4, pp. 27-45.

Furtado, D. (2006). Human capital and interethnic marriage decisions. Bonn: Institute for the Study of Labor (IZA Discussion Paper No. 1989).

Giddens, A. (1993). The transformation of intimacy: Sexuality, love, and eroticism in modern societies. Stanford, CA: Stanford University Press.

Gilbertson, G. A., Fitzpatrick, J. O. \& Yang, L. (1996). Hispanic intermarriage in New York City: New evidence from 1991. International Migration Review, Vol. 30, pp. 445-459.

Gordon, M. M. (1964). Assimilation in American life. New York: Oxford University Press.

Grossbard-Schechtman, S. (1993). On the economics of marriage: A theory of marriage, labor and divorce. Boulder. Westview Press.

Henz, U. \& Jonsson, J. O. (2003). Who marries whom in Sweden? In; H.-P. Blossfeld \& A. Timm (Eds), Who marries whom? Educational systems as marriage markets in modern societies. Dordrecht: Kluwer Academic Publisher, pp. 235-266.

Jasso, G., Massey, D. S., Rosenzweig, M. R. \& Smith, J. P. (2000). Assortative mating among married new legal immigrants to the United States: Evidence from the New Immigrant Survey Pilot. International Migration Review, 34(2), pp. 443-459.

Kalmijn, M. (1991a). Status homogamy in the United States. American Journal of Sociology, 97, pp. 496-523.

Kalmijn, M. (1991b). Shifting boundaries: Trends in religious and educational homogamy. American Sociological Review, 56, pp. 786-800.

Kalmijn, M. (1993). Spouse selection among the children of European immigrants: A comparison of marriage cohorts in the 1960 census. International Migration Review, 27(1), pp. 51-78.

Kalmijn, M. (1998). Intermarriage and honogamy: Causes, patterns, and trends. Annual Review of Sociology, Vol. 24, pp. 395-421.

Kalmijn, M \& van Tubergen, F. (2006). Ethnic intermarriage in the Netherlands: Con-firmations and refutations of accepted insights, European Journal of Population, 22, pp. 371-397.

Kohn, M. L. (1977). Class and confirmity. Chicago: University of Chicago Press.

Lewis, S. K. \& Oppenheimer, V. K. (2000). Educational assortative mating across marriage markets: Non-Hispanic whites in the United States. Demography, 37(1), pp. 29-40.

Lichter, D. T. \& Qian, Z. (2001). Measuring marital assimilation: Intermarriage among natives and immigrants. Social Science Research 30, pp. 289-312. 
Lievens, J. (1998). Interethnic marriage: Bringing in the context through multilevel modelling. European Journal of Population, 14, pp. 117-155.

Lievens, J. (1999). Family-forming migration from Turkey and Morocco to Belgium: The demand for marriage partners from the countries of origin. The International Migration Review, 33(3), pp. 717-744.

Mare, R. D. (1991). Five decades of educational assortative mating. American Sociological Review, 56, pp. 15-32.

McPherson, M., Smith-Lovin, L. \& Cook, J. M., (2001). Birds of a feather: Homophily in social networks. Annual Review of Sociology, 24, pp. 415-444.

Meng, X., \& Gregory, R. R. (2005). Intermarriage and the economic assimilation of immigrants. Journal of Labor Economics 23, pp. 135-175.

Meng, X. \& Meurs, D. (2006). Intermarriage, language and the economic assimilation process: A case study of France. Bonn: Institute for the Study of Labor (IZA), (IZA Discussion Paper No. 2461).

Muhsam, H. V. (1974). The marriage squeeze. Demography, 11, pp. 291-299.

Niedomsyl, T., Östh, J. \& van Ham, M., (2008, forthcoming). The globalisation of marriage fields. Journal of Ethnic and Migration Studies.

Oppenheimer, V. K. (1988). A theory of marriage timing. American Journal of Sociology, 94, 563-591.

Pencavel, J. (1998). Assortative mating by schooling and the work Behavior of wives and husbands. American Economic Review 88(2), pp. 326-329.

Qian, Z. (1999). Who intermarries? Education, nativity, region, and interracial marriage, 1980 and 1990. Journal of Comparative Family Studies, 30, pp. 579-597.

Qian, Z.; Blair, S. L. \& Ruf, S. D. (2001). Asian American interracial and interethnic marriages: Differences by education and nativity. International Migration Review, 35, pp. 557-586.

Qian, Z. \& Cobas, J. A. (2004). Latino's mate selection: National origin, racial, and nativity differences. Social Science Research, 33, pp. 225-247.

Schoen, R. (1983). Measuring the tightness of the marriage squeeze. Demography, 20, pp. 62-78.

Schröder, L. (2007). From problematic objects to resourceful subjects: An overview of immigrant-native labour market gaps from a policy perspective. Swedish Economic Policy Review, Vol. 14(1), pp. 7-40.

Submitted on/Eingereicht am: 21.04.2009

Accepted on/Angenommen am: 30.11.2009

Addresses of the authors/Anschriften der Autoren:

Aycan Çelikaksoy, Ph.D.

Swedish Institute for Social Research (SOFI)

Stockholm University

S-10691 Stockholm

Sweden

E-mail: aycan.celikaksoy@sofi.su.se

Lena Nekby, Ph.D., Associate Professor

Department of Economics

Stockholm University

S-10691 Stockholm

Sweden

E-mail: lena.nekby@ne.su.se 
Saman Rashid, Ph.D.

Department of Social Sciences

Mid-Sweden University

S-83125 Östersund

Sweden

E-mail: Saman.Rashid@miun.se

\section{Appendix}

Table A1: Variable definitions

\begin{tabular}{|c|c|}
\hline Variable & Definition \\
\hline Ethnic endogamy & $\begin{array}{l}\text { Dummy variable equal to one if individual is in a partnership with someone from the same country } \\
\text { of origin or the same national origin, zero otherwise. See Table } 1 \text { for exact definition. }\end{array}$ \\
\hline Educational homogamy & $\begin{array}{l}\text { Dummy variable equal to one if individual is in a partnership with someone having the same level } \\
\text { of education, zero otherwise. Definition is based on six levels of completed education; short com- } \\
\text { pulsory, compulsory school, secondary, short tertiary, university and PhD. }\end{array}$ \\
\hline $2^{\text {nd }}$ generation & $\begin{array}{l}\text { Dummy variable equal to one if individual is born in Sweden with at least one foreign born parent, } \\
\text { zero otherwise. Reference category is first generation immigrants. }\end{array}$ \\
\hline Years residence & Number of years of residence in Sweden for first generation immigrants. \\
\hline Years education & Number of years of education. \\
\hline Age & $\begin{array}{l}\text { Four categorical variables indicating which age group the individual belongs to: } 18-29,30-39,40- \\
49 \text { or } 50 \text { plus. }\end{array}$ \\
\hline Region of origin & $\begin{array}{l}\text { Eight categorical variables indicating the region of origin of the individual. Region of origin is } \\
\text { based on own country of birth for first generation immigrants and on mother's country of birth for } \\
\text { second generation immigrants unless the mother is born in Sweden, in which case region of origin } \\
\text { is based on father's country of origin. The categories are: EU15, Other Europe (non-Nordic, non- } \\
\text { EU15), North/Central America, South America, Asia/Middle East, Africa and Oceania. }\end{array}$ \\
\hline Sex ratio & $\begin{array}{l}\text { The proportion female to male within each country of origin in estimations on men, and vice versa, } \\
\text { the proportion male to female within each country of origin, in estimations on women. }\end{array}$ \\
\hline Relative group size & $\begin{array}{l}\text { Relative group size is defined as the proportion of females (males) from a given country relative to } \\
\text { the population of females (males) in Sweden. }\end{array}$ \\
\hline Mother's education & Years of education for individual's mother. \\
\hline Father's education & Years of education for individual's father. \\
\hline Parental ethnic endogamy & $\begin{array}{l}\text { Dummy variable equal to one if parents are known to come from the same country of origin, zero } \\
\text { otherwise. }\end{array}$ \\
\hline $\begin{array}{l}\text { Parental educational ho- } \\
\text { mogamy }\end{array}$ & $\begin{array}{l}\text { Dummy variable equal to one if parents are known to have the same level of education, zero oth- } \\
\text { erwise. }\end{array}$ \\
\hline
\end{tabular}

